\title{
ADMONISHMENTS OF BAO SHUYA AND XI PENG
}

\author{
TRANSLATION WITH COMMENTARIES AND REMARKS*
}

\author{
ANDRÁS MÁRK SZEKERES \\ Department of Philosophy and History of Science \\ Budapest University of Technology and Economics \\ 1111 Budapest, Egry József utca 1, Hungary \\ e-mail: szekeres@filozofia.bme.hu
}

\begin{abstract}
In this paper I will offer an English translation of a bamboo manuscript. This manuscript is composed of two texts published in the fifth volume of the Shanghai Museum's Collection of Bamboo Slips from Chu: 'Jing Jian Zei zhi' and the 'Admonishments of Bao Shuya and Xi Peng'. Based on he previous scholarship of these texts and my own observations, I will explain why I choose to read the bamboo slips in the order I read them. This includes the question of treating the two manuscripts as a single one. The central point of this paper is the translation of the text itself. I will also discuss where this text fits into the development of political and omenological thought.
\end{abstract}

Key words: 'Jing Jian Nei Zhi', 'Admonishments of Bao Shuya and Xi Peng', Duke Huan of Qi, Omen Interpretation.

\section{Introduction}

In this paper I will offer an English translation of the text entitled 'Admonishments of Bao Shuya and Xi Peng' (Bao Shuya yu Xi Peng zhi jian 鲍叔牙與隰朋之諫), hence abbreviated as 'Admonishments', which contains a discussion between the famous hegemon Duke Huan of Qi (Qi Huan Gong 齊桓公, reigned 685-643 B.C.E.) and his two ministers Bao Shuya 鲍叔牙 and Xi Peng 隰朋. I will also discuss where this text fits into the development of political and omenological thought.

The two halves of the 'Admonishments' manuscript were published in the fifth volume of the Shanghai Museum's Collection of Bamboo Slips from Chu as two separate texts titled 'Jing Jian nei zhi' (競建内之) and the 'Admonishments of Bao

* I would like to thank the anonymous reviewer, as well as András Várnai and Gábor Kósa for their helpful feedback on earlier versions of this paper. 
Shuya and Xi Peng' (Ma Chengyuan 2005, pp. 163-177). The researchers of the Shanghai Museum originally treated these manuscripts as a single text, but later on, due to the differences in handwriting, decided not to do so. Since then, several studies have voiced criticism of this decision, because the topics of the texts are almost identical and in certain arrangements of the bamboo slips and with certain interpretations of the characters they form a cohesive, continuous text (Chen Jian 2006; Guo Yongbing 2006). ${ }^{1}$ These subsequent publications have convinced Chinese scholars to treat this text as one, and thus it is usually referred to by the title 'Admonishments of Bao Shuya and Xi Peng'. Since 2006 there has been a general consensus on this question in the published papers. ${ }^{2}$

In the text, Duke Huan of Qi witnesses a solar eclipse and he asks Bao Shuya and Xi Peng about the meaning of this omen. They admonish him, and, due to his fright, he responds positively to the criticism. They recall the story of the Shang 商 king Gaozong 高宗 witnessing an omen (a pheasant appearing during a sacrifice) and taking it as a sign to start reforms. The admonishments range over a wide variety of topics: ritual correctness, internal policies aimed at the welfare of the people, strengthening the army, and selection of officials for duty. The text seems to place the focus on the last topic, although it could have contained additional bamboo slips now lost to us, so the proportions might have been different.

In addition to the aforementioned debate about joining the two sections together, there have been many challenges in deciphering the text. Numerous orderings have been proposed for the bamboo slips, and most of the characters have been given multiple interpretations. These problems are interrelated: certain interpretations of the characters support a certain arrangement of the bamboo slips and vice versa. Despite these difficulties, a preliminary translation became possible thanks to the painstaking efforts made by Chinese scholars to decipher the text.

The purposes of this paper are multifold. I will begin with a short introduction of the persons appearing in the text based on traditional sources. Then I will discuss the textual problems (e.g. the ordering of the bamboo slips) and give a translation of the text, with comments after each section. In the second half of this paper, I will try to interpret the political message of the text. Furthermore, I will also give an analysis of the omen interpretation strategy of the text and place it in the intricate history of that field of thought.

\section{Historical Background of the Persons Involved}

All the persons mentioned in this text appear in various, previously known historical sources. Gaozong, who is also known by his temple name Wu Ding 武丁, was an influential king of the Shang dynasty in the 13th century B.C.E. Inscribing oracle bones

\footnotetext{
${ }^{1}$ For the arguments, see section 3 below.

${ }^{2}$ See, for example, Chen Wei (2006), Chen Xuanwei (2005), Li Xueqin (2006), Chen Jian (2006), Yuan Ying (2014).
} 
became a general practice during his reign (Bagley 1999, p. 240, Note c to Table 4.1), and this supports the traditional accounts which identify him as a reformer (Shiji 3.104).

The appearance of a pheasant at a sacrifice to Cheng Tang 成湯 is also mentioned in the traditional sources. There is a chapter in the Shangshu 商書 dedicated to this event, the 'Day of the Supplementary Sacrifice to Gaozong' (高宗肜日). In this text, the appearance of a pheasant was considered as an ominous portent. Gaozong's son, $\mathrm{Zu} \mathrm{Ji}$ 祖己, explained to his father that Heaven had sent a sign to correct his ritual mistake.

On the day of the supplementary sacrifice of Gaozong, there appeared a crowing pheasant. Zu Ji said, 'To rectify this affair, the king must first be corrected.' He delivered accordingly a lesson to the king, saying, 'In its inspection of men below, Heaven's first consideration is of their righteousness, and it bestows on them (accordingly) length of years or the contrary. It is not Heaven that cuts short men's lives; they bring them to an end themselves. Some men who have not complied with virtue will yet not acknowledge their offences, and when Heaven has by evident tokens charged them to correct their conduct, they still say, "What are these things to us?" Oh! Our Majesty's business is to care reverently for the people. And all your ancestors were the heirs of the empire favoured by Heaven - attend to the sacrifices to them and be not so excessive in those to your father.' (Legge 1865, pp. 264-266) ${ }^{3}$

The Shiji 史記 version of this story is less explicit about the mistake of Gaozong and shifts the focus to governmental reform.

'[All] the kings inherited [the duty] to care for the people; there are none among them who are not Heaven's descendants. Sacrifice regularly and do not follow the custom of the discarded Way!' Wu Ding rectified his government and practiced virtue. All under Heaven rejoiced together, and the way of the Yin flourished again. ${ }^{4}$

This story is used in the Admonishments to convince Duke Huan that the solar eclipse is a warning from Heaven and that he should admit his mistakes and reform his government.

The life and activities of Duke Huan of Qi are well detailed in the transmitted sources, because he was the first acknowledged hegemon of the Spring and Autumn

${ }^{3}$ Shangshu (Legge 1865) 18.1-5: 高宗肜日，越有雊雉。祖己曰：「惟先格王，正厥 事。」乃訓于王。曰：「惟天監下民，典厈義。降年有永有不永，非天夭民，民中絕命。 民有不若德，不聽罪。天既孚命正厥德，乃曰：『其如台？』鳴呼！王司敬民，罔非天 扸，典祀無豐于 昵。」

${ }^{4}$ Shiji (1959) 3.103: [...]「王嗣敬民, 罔非天繼, 常祀冊禮于棄道。」武丁修政行 德, 天下咸驩, 殷道復興。.

Translations from the Shiji are my own. Watson's translation often deviates too much from the literal meaning. This is usually done to "westernise" the text. Nienhauser is the other extreme: sometimes he translates expressions word-by-word, which makes his English text hard to understand. I have found Chavannes's French translation to be the most useful. 
period (771-476 B.C.E.). He formed a coalition of the central states against the advance of Chu 楚 in the south and was granted the title of hegemon ( $b a$ 霸) by the Zhou 周 king. He centralised his state, unified taxation, increased the incomes of the treasury and relied on a professional bureaucracy instead of hereditary aristocrats ${ }^{5}$ - many of these reforms are reflected in the 'Admonishments'. Traditional accounts attribute his policies to his chancellor, Guan Zhong 管仲, but he is not even mentioned in the 'Admonishments'. Instead, Guan Zhong's life-time friend, Bao Shuya 鲍叔牙, and another official, Xi Peng 隰朋, are the protagonists in the Admonishments. They are also mentioned in the transmitted sources.

[In his first year] Qi Huan employed Guan Zhong [as his prime minister], he was assisted by Bao Shu, Xi Peng and Gao Xi. They cultivated the government, enlisted soldiers by groups of five families, established the weights and the profit from fish and salt, helped the poor, rewarded the worthy and the capable. Everyone was happy in Qi. ${ }^{6}$

With the economic and military superiority of Qi 齊 over the other states of the Central Plain, he became a hegemon. He led the combined armies of the surrounding states against the northern Rong 戎 barbarians and the southern state of Chu. For this he and his prime minister Guan Zhong are considered the saviours of Chinese civilisation. ${ }^{7}$

Shortly after making a truce with Chu, the Duke came into conflict with the Zhou king. King Hui 周惠王 (r. 676-652) wanted to change his designated heir. In the end, the original heir supported by the Duke and his allies inherited the throne as King Xiang 周襄王 (r. 651-619).

By this time he had a chance to take over the Zhou royalty. In 651 B.C.E., the new king sent a ritual gift of sacrificial meat to the Duke, with the instructions to accept it without bowing down. In the Zuozhuan 左傳 version of the events (9th year of Duke Xi), Duke Huan rejects this honour, because he dares not to appear as equal to the king. In the Shiji version (32.1490), the Duke wanted to accept it, but Guan Zhong convinced him not to. The Shiji (32.1491) also narrates that Duke Huan was planning to claim the Mandate of Heaven, but Guan Zhong dissuaded him. This shows that by the time of the Shiji, the Duke was not considered a very virtuous person, but at least he listened to good advice. This is how the 'Admonishments' text portray him as well.

When Duke Huan died in 643 B.C.E., his many sons fought for the throne. The cook Yi Ya 易牙 and the eunuch Shu Diao 豎刀 were in league with a son named Wukui 無虧. According to the Zuozhuan, Yi Ya convinced the Duke to promise the

\footnotetext{
${ }^{5}$ On the state of Qi during Duke Huan and the reform policies, see Hsu Cho-Yun (1999, pp. 553-557).

${ }^{6}$ Shiji 32.1487: 桓公既得管仲，與鮑叔、隰朋、高傒修齊國政，連五家之兵，設輕重 魚鹽之利, 以贍貧窮, 祿賢能, 齊人皆說。

${ }^{7}$ For Confucius's assessment on their accomplishments, see Lunyu (Legge 1861) 14.17. I will discuss Confucius's mixed feelings toward Guan Zhong below.
} 
throne to Wukui and on his death their supporters staged a coup and placed Wukui on the throne, but his reign lasted for only three months, when the crown prince (Duke Xiao 齊孝公, r. 642-633) returned with the army of Song 宋 (Zuozhuan: Xi; Legge 1872, pp. 172-173).

Later texts vilified Yi Ya and Shu Diao. The Xiaocheng 小稱 chapter of the Guanzi 管子, for example, blames these favourites for starving the Duke to death. In the Shiji version, Guan Zhong warned the Duke against trusting them on his deathbed.

That year [41st year of the Duke] Guan Zhong and Xi Peng both died. When Guan Zhong was ill, Duke Huan asked him 'Who could be the prime minister among the many officials?', Guan Zhong said, 'No one knows his subjects better than the ruler himself.' The Duke asked 'How is Yi Ya?', he replied: 'He killed his son to please the Duke, this is against good sentiment, he is not suitable.' The Duke asked 'How is Kai Fang?', he replied 'He left his parents to serve you, this is against good sentiment. It would be difficult to become intimiate with him'. The Duke asked 'How is Shu Diao?', he replied 'He made himself a eunuch to serve you, this is against good sentiment, it would be difficult to form bonds with him. Guan Zhong died, and the Duke did not heed his words. He kept all three close to him and they monopolised the power. ${ }^{8}$

The conflict between the clique of sycophants and the leading officials, which is central to the 'Admonishments', is well attested in the traditional sources as well.

\section{Arrangement of the Bamboo Slips}

The main reason why the two halves of this text were treated as separate ones in the original Shanghai Museum publication was the presence of two titles, as well as the difference in handwriting. But Chen Jian (2006) showed that the handwriting on one slip from the 'Admonishments' (BXJ \#4) ${ }^{9}$ could be the same as the Jing Jian nei zhi texts. Guo Yongbing (2006) showed that several characters on the JJNZ slips are written by the scribe of the BXJ slips. The most likely explanation is that halfway through the text another scribe took over the writing, and he also proofread and edited the earlier slips.

On the back of JJNZ \#1 is the writing 'Jing Jian nei zhi'. This is where the title of bamboo manuscripts are usually written, but these four characters are not related

${ }^{8}$ Shiji 32.1493: 是歲，管仲、隰朋皆卒。管仲病，桓公問曰：「群臣誰可相者？」管 仲曰：「知臣莫如君。」公曰：「易牙如何？」對曰：「殺子以適君, 非人情, 不可。」公 曰：「開方如何? 」對曰：「倍親以適君, 非人情, 難近。」公曰：「豎刀如何? 」對曰： $\ulcorner$ 自宮以適君, 非人情, 難親。」管仲死, 而桓公不用管仲言, 卒近用三子, 三子專權。

${ }_{9}$ I will refer to the bamboo slips based upon their original ordering in the Shanghai Museum version. Those listed there as parts of the 'Jing Jian nei zhi' text will be referred as JJNZ \#1JJNZ \#10, while the 'Bao Shuya yu Xi Peng zhi jian' slips will be refered as BXJ \#1-BXJ \#9. 
to the contents of the manuscript. One explanation is that one of the possibly missing bamboo slips mentions Jing Jian and somehow explains why this was chosen to be the title. Another possbile explanation is that this is a misplaced title, or perhaps some administrative note (see Li Rui 2007, p 71). This is further supported by the fact that the handwriting is different from what is on the front of the bamboo slip. The last bamboo slip contains what is most likely the real title of the text 'Admonishments' and nothing else. This arrangement of the title is unique among the Chu manuscripts. ${ }^{10}$

When the texts were joined, the bamboo slips had to be rearranged. This is done by examining the sentences that would emerge from joining two bamboo slips together and by considering the rhetorical structure of the text as a whole. The latter is required when the characters are unreadable or there are multiple, possible readings and interpretations (Ma Chengyuan 2005, p. 165). There is almost complete consensus on the order of the bamboo slips ever since Chen Jian joined the two halves together. Li Xueqin (2006) removed one slip from the text (JJNZ \#7) and rearranged the surrounding slips, but I will argue below that Chen Jian's ordering is preferable.

The order of the 'Jing Jian nei zhi' slips is: \#1-\#5-\#6-\#2-\#7-\#4-\#3-\#8-\#9-\#10. These are followed by the 'Admonishments' slips: \#4-\#5-\#6-\#7-\#3-\#1-\#2-[...]-\#8-\#9.

JJNZ \#1 starts with the Duke witnessing a solar eclipse and inquiring about its meaning. ${ }^{11}$ Upon hearing about how ominous this event is, the Duke wants to exorcise it with a prayer (JJNZ \#5-\#6). He is scolded for this suggestion and told the parable of Gaozong who upon seeing an omen, reformed his government (JJNZ \#2\#7-\#4-\#3). Upon hearing this, the Duke practices self-criticism for which he is applauded by the two officials (JJNZ \#8-\#9) who then go into details about the governmental mistakes of the Duke. Central of these problems is that two sycophants, Shu Diao and Yi Ya, had control over the government (JJNZ \#10-BXJ \#4-\#5-\#6). The Duke asks for advice (BXJ \#7), then he proclaims a chain of reforms (BXJ \#3-\#1\#2). The end of the text reports that in that year, all the calamities have been diverted (BXJ \#8). There were probably further slips after BXJ \#8, detailing more reforms and a longer discussion of the results of the reforms. The last bamboo slip contains only the title of the text (BXJ \#9).

\section{Translation of the Text}

I have broken up the text into sections based on content. Explanations about the translation of single characters or short expressions will appear in footnotes, while questions about the structure of the text will be explained in detail following the translation of each section. Unless otherwise noted, I followed Li Xueqin's transcription.

\footnotetext{
${ }^{10}$ For the discussion of this problem, see Chen Jian (2006).

${ }^{11}$ There is consensus on starting the text with this bamboo slip; see, for example, Li Xueqin (2006, p. 91).
} 


\title{
【競建 $1:$ 競建内(納)之 Received $^{12}$ from Jing Jian
}

On the back of JJNZ \#1 there are four characters. It was originally thought to be the title of the first half of the text. As I discussed above, BXJ \#9 is a more likely candidate for the title and this could be an administrative note or a misplaced title of another manuscript.

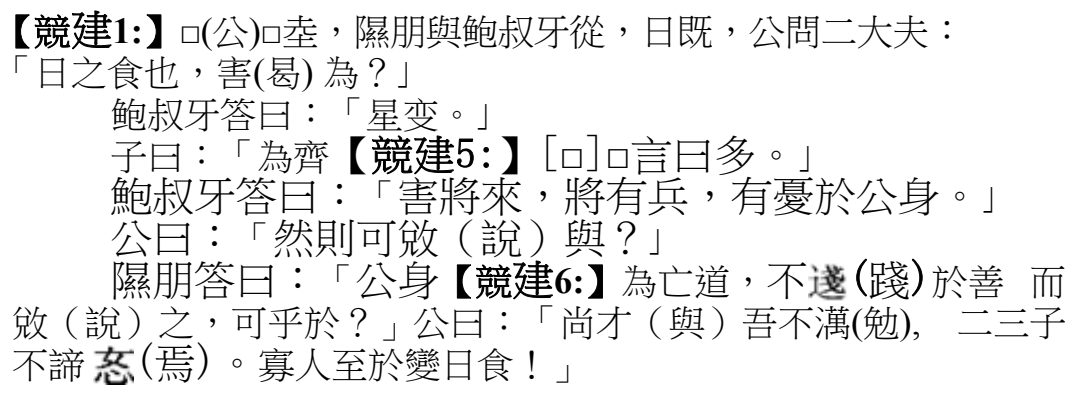

\begin{abstract}
... Xi Peng and Bao Shuya accompanied him when the Sun was completely [eclipsed]. The duke asked the two ${ }^{13}$ officials: ${ }^{14}$ 'What ${ }^{15}$ caused this solar eclipse?' Bao Shuya replied 'It is an omen of the stars. ${ }^{, 16}$ The duke $^{17}$ said, 'For Qi [...]' [JJNZ \#5:] [...] tells many.' Bao Shuya replied: 'Harm will ${ }^{18}$ come, there will be war, and grief will befall the duke
\end{abstract}

${ }^{12}$ Following Li Xueqin's (2006, p. 93) suggestion to read 内 nei as 納 $n a$.

${ }^{13}$ Another possibility was suggested by He Youzu. He reads this character as shi 士, because there is a small vertical stroke in the character (He Youzu 2006). In this case the sentence would mean that the duke asked the officials of various ranks.

${ }^{14}$ The characters for $d a f u$ 大夫 are written together as a ligature, see Ma Chengyuan (2005, p. 167)

${ }^{15}$ The characters for $h a i$ 害 and he 曷 can stand in place of each other, so most scholars suggest the reading 'What caused this solar eclipse', including Ma Chengyuan (2005, p. 167). Li Xueqin rejects the interpretation of 害 as 曷, so according to him, the sentence means 'Is this solar eclipse harmful?'. He Youzu (2006) noted that on the 5th bamboo slip, where this character certainly means 害, its style is slightly different, so it is more likely that here it means 曷.

${ }^{16}$ In omenological contexts, bian 變 change indicates an abnormal, irregular event which is ominous. The concept of stars includes the planets and the two luminaries as well.

${ }^{17}$ Here the text actually says 子曰 'the master said', but that does not make any sense here, it is probably the duke who is asking another question. Li Xueqin $(2006$, p. 91) suggested that the scribe wanted to write 'the duke said', but wrote 'the master said' out of habit. Chen Wei (2006) suggested to read 子 as 災, and interpreting 曰 as 'Sun' and not 'say'. Thus, instead of having two lines spoken by two different persons, Bao Shuya said 'abnormality of the stars, calamity of the Sun for Qi ...'. He believes that besides the solar eclipse there was another abnormality among the celestial bodies at the same time. Chen Xuanwei (2005) agrees with his reading, but he does not suppose another unusual celestial phenomenon. He believes this refers to the positions of the stars at the time of the eclipse.

${ }^{18}$ Chen Wei (2006), who believes that the text is about two distinct celestial phenomena (see previous footnote), reads jiang 將 as qiang 槍, which were homophones. The sentence according to him is as follows: 'The harmful Qiang star is coming, Qiang brings war and danger for the 
himself!' ${ }^{19}$ The duke said, 'If it is so, can a prayer ${ }^{20}$ avert it?' Xi Peng replied: 'The duke himself [JJNZ \#6:] has lost the Way, does not tread on the good [Way] and wants to pray about it, how could this be possible? ${ }^{21}$ The duke said, 'Alas! ${ }^{22}$ I was not urged [to change my ways], ${ }^{23}$ the officials did not criticise $\mathrm{me}^{24}$, and this is how I got to the point where the calamity of the solar eclipse [occurred]!?'

The first sentence is damaged, the first two graphs are missing, only a horizontal stroke from the bottom of the second graph is visible (Li Xueqin 2006, p. 91). It is deducible from the following sentences that it is about the duke doing something, where he is accompanied by Bao Shuya and Xi Peng. Bao Shuya used to be the tutor of Huan, so they must have been among the highest ranking ministers of the state.

Unlike Professor Li (2006, p. 90), I do not find it compelling to suppose a now missing bamboo slip after the first one. But since the first graphs of the next bamboo slip are damaged as well, we cannot hope for a definite solution.

The interpretation of the duke's last line here is rather difficult. Many readings have been offered for the fifth character man 澫, most interpreting the sentence as self-criticism: 'I lack talent' or 'I did not make an effort'. This would lead us to interpret $\ulcorner$ 二三子不諦 $\lrcorner$ as the next sentence, where the duke complains for not being criticised by his officials (see Li Xueqin, 2006, p. 92).

But if the duke did indeed voice such a serious self-criticism at this point, why is he only applauded for taking the blame in JJNZ \#9 and not here? Bao Shuya and Xi Peng wanted to remonstrate with the Duke, so after he admitted his errors, why would they absolve him in the very next sentence by stating 'this is the fault of the officials'? And why would they tell him the story of Gaozong if he already realised that lack of criticism is a problem?

Duke himself.' He cites Han sources that the Qiang star was associated with military uprisings, drought and disease. This is rather conjectural, and the text speaks about flood, not drought. Furthermore, the text does not really support these emendations about two different omens. For example, at the end of JJNZ \#6 the Duke speaks only about the solar eclipse.

${ }^{19}$ This sentence is very similar to another one found in Baoshan, see Li Xueqin (2006, p. 91). Most likely it means that the duke will suffer some disease.

${ }^{20}$ This word 攽 frequently appears on Chu bamboo slips as a form of prayer to exorcise calamities (Personal communication from Sándor P. Szabó).

${ }^{21}$ The last character of the sentence was inserted after the next character had already been written, perhaps during proofreading, see Ma Chengyuan (2005, p. 172). Therefore, it is very difficult to read it, but it certainly resembles 於 (as transcribed in the original publication) more than 才, as interpreted by Chen Jian (2006).

${ }^{22}$ Many researchers (Chen Xuanwei 2005, Li Xueqin 2006, p. 91, He Youzu 2006) agree to read these two characters as an exclamation 甚哉, so I used their reading. In the original publication (Ma Chengyuan 2005, p. 165) this was transcribed as 尚才. Chen Jian (2006) suggested to read 才 as 在 or 於, emphasising that the following personal pronoun is the passive object of the verb, just as I suggested in my reading.

${ }^{23}$ Many interpretations have been given for the character 澫. For an overview of the problem, see Lin Zhipeng (2007b). The majority of them interprets it as 'lacking talent' or 'not making effort. However, it seems to me that this sentence is not a self-criticism, see below.

${ }^{24}$ Reading 安 as 焉. 
Thus, instead of interpreting these sentences as self-criticism, we should interpret them as the Duke arguing that he was not criticised at all, so how could his ways be so bad to incur the calamity of the solar eclipse. With this reading the following sections make perfect sense. The duke is unwilling to admit his faults and he takes the lack of criticism as indicative of his good government. So they tell him the story of Gaozong which is exactly about this misunderstanding: lack of criticism is not an indicator of doing well, but on the contrary, it shows that people have already given up on the ruler. Only after this does the Duke accept that he has indeed lost the Way, and only after that is he applauded.

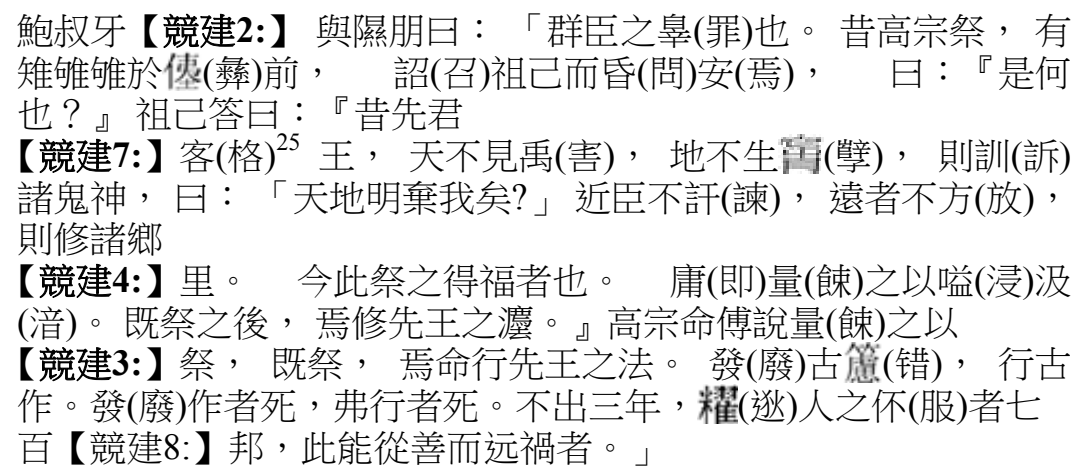

Bao Shuya [JJNZ \#2:] and Xi Peng said 'It is the fault of the ministers. In the past, when Gaozong was conducting a sacrifice to his ancestors, a pheasant crowed in front of the vessel. ${ }^{26}$ He called for $\mathrm{Zu} \mathrm{Ji}$ and asked him about it: "What is the meaning of this?" Zu Ji replied: "The former lord $^{27}$ [JJNZ \#7:] [had a] pattern [which should be followed] by the king: '[When] Heaven is not showing us an omen, Earth not generating misfortunes, then you should ask all the various spirits that "Have Heaven and Earth abandoned us?"28 [when] the officials close by do not admonish [you], those far away do not feel free to do so, ${ }^{29}$ then you

${ }^{25}$ I follow Chen Jian's (2006) reading of this graph.

${ }^{26}$ Several explanations have been offered for this character. Chen Jian argues that in Chu calligraphy 弓 and 人 as lateral components were interchangeable, so this character is a variant for 费, meaning $y i$ 彝, ritual wine vessel. Li Xueqin (2006, p. 92) takes $y i$ 夷 as the phonetic element, and translates the character as shi , the impersonator of ancestors during sacrifices. Fan Changxi (2006) and Liu Lexuan (2006) discuss the various suggestions and they both reach the conclusion that we should interpret this as the wine vessel, which is also supported by the Shangshu version of the event.

${ }^{27}$ This probably refers to Pan Geng 盤庚, as suggested by Li Xueqin (2006, p. 92). Pan Geng was Gaozong's uncle. According to the Shiji (3.102), he restored the laws of Cheng Tang and restored the majesty of the Shang after long generations of internal strife. This makes him a good example for the restoration of the laws of the ancient kings.

${ }^{28} \mathrm{I}$ am following Gao Youren's (2008) suggestions to interpret this section as an inquiry, and not as a statement.

${ }^{29}$ I am following Liu Lexian's (2006) suggestion in interpreting this character, who quotes parallel sentences from the Shuoyuan. 
should cultivate [ties with] the various hamlets and [JJNZ \#4:] villages.' Now with this sacrifice we can obtain a blessing. Promptly cook meat in that sacrificial vessel, ${ }^{30}$ and after the sacrifice, practice the laws of ancient kings with it!" Gaozong ordered Fu to sacrifice the food [JJNZ \#3:], and after the sacrifice he gave orders to employ the laws of the ancient kings. He discarded what the ancients considered an error, and kept using what the ancients accomplished. Those who discarded what the ancients accomplished died, ${ }^{31}$ those who did not keep using [what the ancients accomplished] died. ${ }^{32}$ It did not take three years, and seven hundred faraway ${ }^{33}$ cities submitted. [JJNZ \#8:] This is the case of being able to follow good and keep away ${ }^{34}$ misfortune.'

This is the only part of the text where there is no consensus on how to order the bamboo slips. It starts at JJNZ \#2, where Xi Peng introduces the story of Gaozong witnessing an omen and asking $\mathrm{Zu}$ Ji to interpret it. $\mathrm{Zu}$ Ji starts speaking about the times of the former king, introducing another nested story. The question is how to arrange JJNZ \#3, \#4, \#7 and whether to suppose additional, now-lost slips or not.

We can anchor JJNZ \#4 as the middle of the section. It contains the conclusions of Zu Ji's speech. Aside the first character, it contains four sentences, the last one incomplete. The first sentence states that a blessing has been obtained with the sacrifice, followed by a suggestion concerning the ritual. The third sentence recommends that the laws of the former kings should be restored after the ritual. In the last one Gaozong orders Fu to carry out the first suggestion.

It follows that there must be a section before JJNZ \#4 where Zu Ji offers an argument for his recommendations, and there must be a section after it, where his second recommendation, the restoration of the laws of the former kings, is carried out by Gaozong.

JJNZ \#3 can be either of that. The first character also belongs to a previous sentence, but the rest states that after the sacrifice, somebody ordered the restoration of the laws of the former kings, how he did it, and the good results of it. \#3-\#4, \#4-\#3 and \#3-\#8 all offer acceptable sentences when joined.

${ }^{30}$ On the transcription of this part, see Li Xueqin (2006, p. 92). Yang Zesheng (2006) offers a different transcription, but with the same general meaning.

${ }^{31}$ In the Shujing (Legge 1872, p. 341) version of this event, Zu Ji talks about the early death of those who do not conform to Heaven.

${ }^{32}$ The juxtaposition of the two subsentences here is somewhat awkward, because it is hard to see the difference between discarding and not following something. The parallel structure would make much more sense if it said "those who discard what the ancients accomplished were executed, those who kept using what the ancients considered an error were executed", but that is not what is written in this manuscript.

${ }^{33}$ Most scholars read this character as $d i$ 狄, the name for a barbarian ethnic group. Chen Wei (2006) argued that 700 towns of the di make little sense, so he suggested to read it as 逖 instead of 狄.

${ }^{34}$ I followed Li Xueqin's transcription here. In the original transcription this character was identified as $q u$ 去 with an additional 定 radical. In this case the sentence means 'follow good and expel misfortune'. 
As for JJNZ \#7, the first two characters are slipovers from the previous sentence. Besides those, it contains an almost complete parallel rhetorical structure, that Heaven and Earth not producing omens is a problem just like not getting criticism from officials, and while in the first case the spirits should be addressed, in the second case the towns and villages. Li Xueqin (2006, p. 90) suggested to discard it as belonging to another text despite the same handwriting. I disagree: JJNZ \#7 has a central role in the argument.

It introduces two important ideas: first, it states that when the ruler is not criticised, it is not a sign of him doing good; on the contrary, it is a problem. Duke Huan's last line was about not being criticised and Xi Peng introduced Gaozong's story by stating that 'it is the fault of the ministers'. Without JJNZ \#7, it would be quite unfathomable how Gaozong's story fits into the flow of the conversation. Also after hearing this story, the duke states 'I did not know that it was bad!'. This must refer to the lack of criticism.

Second, JJNZ \#7 offers a re-evaluation of omens. Instead of being calamities that should be diverted by prayer, they are warnings which should be welcomed. It is the lack of warnings that signals the demise of a ruler. This explains $\mathrm{Zu}$ Ji's statement that the sacrifice with the omen was a blessing. It is not an inherently good omen, it is only good by creating a chance for correction. Without JJNZ \#7, why would Xi Peng tell duke Huan a story about an omen $\mathrm{Zu}$ Ji claims to be auspicious after convincing him that the omen of the eclipse is ominous?

The only way we can fit together the bamboo slips without supposing any additional ones is the order \#2-\#7-\#4-\#3-\#8 as suggested by Chen Jian (2006). This makes JJNZ \#7 to be Zu Ji's argument to take the omen as a sign to reform the government and turn it into an auspicious one, which Gaozong did with good results. Even if we do suppose now-lost slips, the only other meaningful order would be \#2\#7-...-\#3-\#4-...-\#8.

公曰：「吾不智其為不善也。今内之不得百姓，外之為諸侯笑 (朝)，寡人之不【競建9:】畱(当)也，幾(豈)不二子之憂也哉！」 隰朋與鲍叔牙皆拜，起而言曰：「公身為亡道，進寺 (华)倗(孟) 子，以(與)馳于倪【競建10:】延，迨达(逐)畋，紾(鄉)亡(無)旗； 或以豎习與易牙為相，二人也，朋黨辜(群)獸(醜)，婁朋取與， 口(厭) 公拀 (教)而簥 (睽)【鮑叔牙4:】之, 不以邦家為事, 縱公 之所欲庚(更)。民繵(弗)樂, 毒甚倍願, 疲弊齊邦。日成(盛)于 縱, 弗顾前後, 百【鮑叔牙5:】姓皆怨 (悒)

点(悁), 鹽(酒) 然将喪 (亡)。公弗詰, 口(亲)臣雖欲试, 或(又)不 得見。公沽(故)弗察人之生三:食色憂。

今豎习佖(匹)夫而欲【鮑叔牙6:】智(知) 萬乘之邦而贵井 (主)， 其為災也深矣；易牙人(刀)之與者而食人，其為不仁厚矣。公弗 圖，必害公身。」公曰：「然则奚【鮑叔牙7:】如？」鲍叔牙答 日：「齊邦至惡死而上秋(稠)其刑, 至欲食而上厚其斂, 至惡何 (苛) 而上不時吏 $($ 使)。」 
The duke said, 'I did not know why it [i.e. the lack of criticism] was not good. Now at home, I do not possess [the support of] the people, and abroad the feudal lords laugh [at me]. ${ }^{35}$ That I am [JJNZ \#9:] unworthy, ${ }^{36}$ how could this not worry you two?' Xi Peng and Bao Shuya both kowtowed before him, then rising up they said, 'The duke acts as he forgot the Way, taking Hua Mengzi and riding off to Niting, ${ }^{37}$ [JJNZ \#10:] while at the hunt, his banner ${ }^{38}$ is missing.

If Shu Diao and Yi Ya are employed as officers (xiang), these two form a clique, gathering a cabal of supporters. ${ }^{39}$ They detest ${ }^{40}$ educating the duke and [so they] oppose [BXJ \#4:] it, [they do not want you] to pay attention to the business of the state, so they indulge you in your desires even more. The people are not happy about it, ${ }^{41}$ [because] their chores ${ }^{42}$ are multiplied against their desires, and thus the state of Qi is exhausted and abused. [You] indulge [yourself] every day, and do not care for the past and the future, [BXJ \#5:] [while] the hundred clans are all worried, nervous and frightened that they are going to perish. ${ }^{43}$

The duke did not investigate this. [Although we,] the ministers $\operatorname{close}^{44}$ [to the Duke] wanted to remonstrate, but [we] did not gain

${ }^{35}$ There is another possibility here. Following Ji Xusheng's analysis Chen Wei (2006) interpreted the character 笑 as 朝, in the sense of 朝見, that is, having an audience with the king. During the middle period of Duke Huan's reign, the Zhou court was involved in diplomatic moves against the hegemony of Qi. Therefore, the sentence 'Now at home I do not possess the support of the people and abroad the feudal lords have audiences with the king' would make sense.

${ }^{36}$ The character is transcribed as 㓢 which belongs to the same phonetic group as 肖. Li Xueqin (2006, p. 92).

${ }^{37} \mathrm{Niting}$ is the name of a place, most likely inside the state of Qi.

${ }^{38}$ For the explanation of the role of the hunt, see Li Xueqin (2006, p. 92).

${ }^{39}$ Xuan Jiancong (2006) suggested a slightly different interpretation: he left 獸 as it is, but reads 婁 as 邀, so according to him the sentence means 'a group of wicked people, inviting a clique'. The general meaning of the section is the same.

${ }^{40}$ The right side of this character is blurred. On the basis of a similar radical from the Guodian 郭店 Laozi, Chen Jian (2006) suggested to read it as 厭.

${ }^{41} \mathrm{I}$ am following Li Xueqin's interpretation here in reading 矙 as fu 弗 to arrive at the translation 'not happy about it'. Chen Jian reads this graph as 獵 lie (hunt), which is more plausible on a character level, but makes less sense in the context. I am not aware of the word 獵 being used in a metaphorical sense of 'chasing happiness'.

${ }^{42}$ The transcription and the meaning of this sentence is under debate. I follow Li Xueqin's transcription and his interpretation of 毒 as labour, Li Xueqin (2006, p. 93).

${ }^{43}$ There are difficult characters in this sentence. Li Xueqin transcribed it as「酒然将亡」 while Chen Jian as 「鹽( 奄)然将喪」. See Fang and $\mathrm{Na}$ (2008) on a detailed discussion of the first half of the sentence. See Fang Yong (2006) and Lin Zhipeng (2007a) for further analysis of the last character. Although it is difficult to settle the exact character, the meaning of the sentence is clear.

${ }^{44}$ The interpretation of the character standing before 臣 (ministers) is difficult. In the original transcription it was considered part of the previous sentence as 兴蜀. Xuan Jiancong (2006) transcribed it as 觸, in the sense of being in touch to reprimand. This interpretation is problematic, because the text speaks about the officials not getting audience to admonish the Duke. Chen Wei (2006) interpreted this character as 親, which is preferable. 
audience. The duke therefore did not investigate the three [basic parts] of the life of people: eating, sex, ${ }^{45}$ and worry. ${ }^{46}$

Now, Shu Diao is but an ordinary man, yet he desires [BXJ \#6:] to be known as the master of a state of ten thousand chariots. The disaster this leads to will be serious. Yi Ya is in league with Diao ${ }^{47}$ and he feeds (your) people. ${ }^{48}$ His acts are not benevolent and generous. If the duke does not plan against this, he will certainly suffer harm [from this].' The duke said, 'If it is so, what should I do instead?' [BXJ \#7:] Bao Shuya replied, 'The [people of the] state of Qi detest death, but those above just multiply (or: mete out) the punishments. They desire to eat, but those above just increase the taxes. They detest severity, yet those above order them [to work] at wrong times.'

The last three sentences of Bao Shuya can be interpreted in two different ways, depending on how we decipher the verb before the 'punishments'. Chen Wei (2006) pointed out that the duke asked how to govern better, therefore it would make sense if the sentences described good government: 'The [people of the] state of Qi detest death, so those above should mete out punishments very carefully. They desire to eat, so those above should consider the taxes seriously. They detest severity, so those above them should not order them [to work] too often.' But the grammar of this interpretation is forced. The description of bad government is more faithful to the text. In that case Bao Shuya answers the Duke's question by pointing out what should be fixed.

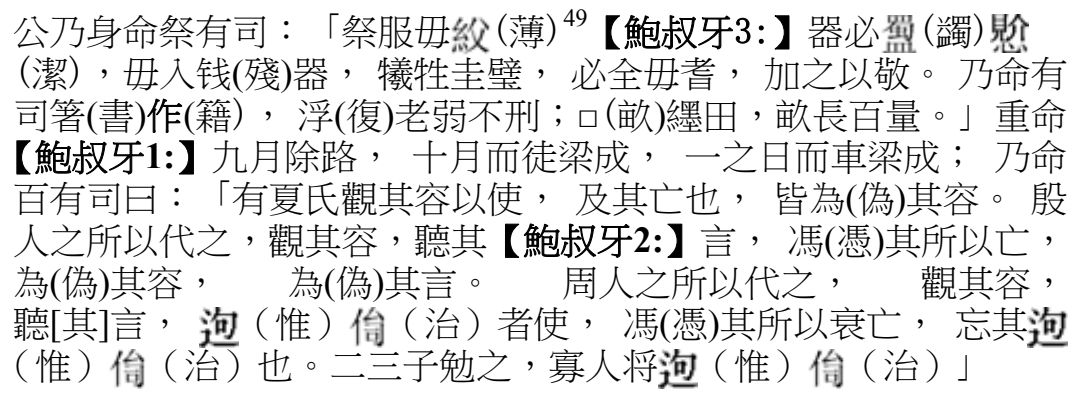

\footnotetext{
${ }^{45}$ Mencius 6A (Gaozi I.4) has a similar sentence, which says,「食色，性也。」.Se 色 is an euphemism for sexuality (Legge 1875, p. 308).

${ }^{46}$ For the analysis of the interpretation of this character, see Hou Naifeng (2008). He reaches the conclusion that it means "to rest" and not "worry", but he uses a Northern Song Dynasty commentary to the Heguanzi 鶡冠子 to arrive at this conclusion, which I do not find convincing enough.

${ }^{47}$ I follow Chen Jian (2006) in reading 人 as 刀, meaning Э, that is, Shu Diao, and not amending the 與 later in the sentence to 邪 (evil). The other transcription is 易牙人之邪者 which would mean 'Yi Ya is an evil man'.

${ }^{48} \mathrm{Yi}$ Ya is infamous for cooking his own son and serving it to Duke Huan, when he mentioned that the only meat he never tasted was human flesh.

${ }^{49}$ On the interpretation of this character, see Li Xueqin (2006, p. 93).
} 
Then the duke himself ordered the official responsible for the sacrifices: the sacrificial robes cannot be of poor quality. [BXJ \#3:] The [sacrificial] utensils must be clean and pure, damaged utensils cannot be used. The sacrificial gui and bi [jades] must be whole and faultless. ${ }^{50}$ Moreover [they] must be used respectfully. Furthermore, [the duke] ordered the officials to create a register [of the population], to exempt the old and the weak from punishments. The lands should be parcelled out, each parcel long enough [to produce] a hundred liang. ${ }^{51}$

He gave a strict order [BXJ \#1:] for the roads to be repaired in the ninth month, the foot bridges in the tenth, on the same day together with the bridges for carts and chariots. ${ }^{52}$ Then he ordered the hundred officials, saying 'During the Xia they looked at the appearance of those they had in employment. ${ }^{53}$ Their downfall is all due to appearance being misleading. The people of Yin [Shang] changed this: [besides] looking at their appearance, they listened to their [BXJ \#2:] speech. The basis of their downfall was that appearance and speech are [both] misleading. The people of Zhou changed this [again], they looked at their appearance, listened to [their] speech and examined their governmental achievements. ${ }^{54}$ The cause of their decline and fall was forgetting to examine the governmental achievements. Some officials put an effort into this [governmental achievements], and I shall examine only the governmental achievements in the future.'

It was at the time of Duke Huan when the hereditary officers were replaced by selected ones, so the methods of selection were quite crucial. The Xia 夏 method probably refers to physiognomy and the Shang method to oratory skills. Hu Qiong (2007) suggested a more positive interpretation of the Xia and the Shang methods: judging by demeanour and testing skills in debate. The text clearly considers their methods ineffective. Judgement by demeanour and by debate skills are also frowned upon in the Xunzi 荀子. ${ }^{55}$

${ }^{50}$ Li Xueqin (2006, p. 93) suggested to take 者 to be 恶 based on the Book of Odes.

${ }^{51}$ Distribution of lands is a well established topos for good and benevolent government. Li Xueqin (2006, p. 93) believes that the text talks about breaking up empty lands. Chen Jian (2006) offers a different interpretation: according to him, the text is about the establishment of various sizes for fields, and it is related to taxation. Xuan Jiancong (2006) believes that all of these decrees are connected to how the population register should be used.

${ }^{52}$ Lin Zhipeng (2007b) suggested to amend 一之日 as 十一月, which means that the repair of the bridges for carts and chariots is for the eleventh month. Both readings are plausible.

${ }^{53}$ Another interpretation is 'looked at the appearance [of a candidate], then employed him'. The question is whether it is about selecting officials for employment or about performance reviews and promotions? Both are plausible in this context, but the past performance version makes more sense with the 'Zhou method'.

${ }^{54}$ The interpretation of the first of these two characters, the whole point of this paragraph, is quite difficult. I follow Dong Shan (2007) here, who based his interpretation on parallel sentences in other sources.

${ }^{55} \mathrm{See} \mathrm{Hu}$ Qiong (2007) for the discussion of this topic. 
【鮑叔牙8:】是岁也, 晉人伐齊, 既至齊地, 晉邦有乱, 師乃歸。 粤坪(平)地至膝, 复。日榫 (璚), 亦不為災, 公(虹)掻（煇）, 亦不為害

[BS \#8:] That year, the people of Jin 晉 attacked Qi. They were already inside the land of Qi, when back at Jin there was a rebellion, so their army returned [home]. The spontaneous rising of the earth was knee high [but then it receded]. ${ }^{56}$ The spikes of the $\operatorname{sun}^{57}$ have not caused a disaster, the omen of rainbow ${ }^{58}$ has not caused any harm.

\section{【鮑叔牙9:】。一鲍叔牙與隰朋之諫}

[BS \#9:] The admonishments of Bao Shuya and Xi Peng

If we compare the criticisms, the reforms and the good results, there are serious discrepancies among them. Both the criticisms and the good results touched upon military affairs, but the text mentions no military-related reforms. Promotion of officials, welfare of the people, and taxation were the central topics of the criticism and the reforms, but these topics do not appear in the description of the results of the reforms. Instead, further ominous portents are mentioned to be resolved. It is strange that they were not introduced earlier, although they might be stock examples of a happy end. Altogether there is a high possibility that there were additional bamboo slips that dealt with these topics between BXJ \#2 and BXJ \#8.

\section{The Political Message of the Text}

This text uses a historical framework to talk about governmental reforms, specifically the selection of worthy officials instead of sycophants, so it is easy to see it fitting into the literature of 'criticising the present using the past'.

As far as we can classify pre-imperial texts into philosophical schools, this appears to be a $R u$ 儒 text. Ritual correctness is mentioned first among the reforms Qi Huan Gong made after he had been rectified - which is a hallmark topic for the $\mathrm{Ru}$. The topic of the selection of officials is also central to the Ru and to this text as well, but it also interested other traditions, most notably the Legalists 法家. In this text great emphasis is placed upon how mistaken it is to place too much burden on the population, a mistake traditionally associated with Legalists.

${ }^{56}$ In later omenological works, this phenomenon was called di zi zhang 地自長 (Li Xueqin, 2006, p. 95). A very different interpretation was offered by Yuan Ying (2014), who reads 膝 as 范, the name of a place between Qi and Jin. In this interpretation this sentence is related to the attack from Jin, and not part of a list of new omens.

${ }_{57}$ Another ominous phenomenon when the sun seems to have spikes along its rim (Li Xueqin 2006, p. 95).

${ }_{58}$ Another omen in the sky, its exact identification is difficult (Li Xueqin 2006, p. 95), it may mean some kind of halo in the sky. 
A more subtle, but interesting political message is the selection of protagonists for this text. Guan Zhong, the most famous minister of Qi Huan Gong, is absent from the story told here. Guan Zhong was the most important minister of Qi Huan Gong, his importance in creating the hegemony of Qi was even mentioned in the Lunyu 論語:

The master said, 'Guan Zhong acted as prime minister to the duke Huan, made him leader of all the princes, and united and rectified the whole kingdom. Down to the present day, the people enjoy the gifts which he conferred. But for Guan Zhong, we should now be wearing our hair unbound, and the lappets of our coats buttoning on the left side.' (Legge 1861$, pp. $145-146)^{59}$

Later sources, for example the Shiji, attribute him almost everything achieved by Qi Huan Gong, making him the superstar of his reign. ${ }^{60} \mathrm{He}$ was also the one who opposed Yi Ya and Shu Diao and (according to the Shiji) these two only gained power after his death. So why is it that in the "Admonishments" text he is not even mentioned?

Despite his fame, Guan Zhong's reputation is somewhat ambivalent. In the Analects we see that Confucius has a very ambivalent evaluation of him, he criticises him for usurping the ritual prerogative of rulers: ${ }^{61}$

The master said, 'Small indeed was the capacity of Guan Zhong! [...] If Guan knew the rules of propriety, who does not know them?' (Legge 1861$, pp. $26-27)^{62}$

The first advice given in the 'Admonishments' is about ritual correctness, so it is reasonable why these two ministers were chosen instead of Guan Zhong to be the protagonists. Furthermore, by the late Warring States 戰國 period (476-221 B.C.E.) Guan Zhong is viewed as a proto-Legalist (Graham 1989, pp. 100, 267), so if the writers of the 'Admonishments' were hostile towards Legalism, they had good reason to disfavour him. In the 'Admonishments', placing too much burden on the population is one of the governmental mistakes for which the Duke is admonished. This is a mistake for which Legalists are often criticised. Guan Zhong is indeed famous for the taxation system he introduced in Qi, so the criticism of his reforms might even be implied in this text.

An interesting thing about Guan Zhong is that his role was most likely exaggerated over time. If we look at the Zuozhuan, there are long periods where Guan

${ }^{59}$ Lunyu 14.17: 子曰：「管仲相桓公， 霸諸侯，一匡天下，民到于今受其賜。微管 仲，吾其被髮左衽矣。

${ }^{60}$ Shiji (62) contains the biography of Guan Zhong.

${ }^{61}$ Lunyu (14.17) also raises the moral dilemma caused by Guan Zhong not committing suicide when his first patron, the brother of Duke Huan died. This topic is investigated in Henry (1987). Graham (1989, p. 107) also points out (in a somewhat detractive tone) that evaluating Guan Zhong was a central question for the early Confucians.

${ }^{62}$ Lunyu 3.22: 子曰：「管仲之器小哉！」[...]管氏而知禮, 孰不知禮? 
Zhong is not mentioned at all. Instead, we find that the eunuch Shu Diao led the armies of Qi in 658 B.C.E. many years before Guan Zhong's death. The Zuozhuan also tells us that in 650 B.C.E. it was Xi Peng who, working together with the Zhou king's envoy, led the Qi army and settled the Jin succession dispute. So the omnipresent influence of Guan Zhong - as portrayed in the Shiji - is most likely an exaggeration. Therefore his absence from this text then is either an active downplay of his importance or simply a more authentic portrayal in accordance with the Zuozhuan. ${ }^{63}$

\section{Remarks about Omen Interpretation in the Text}

The first half of the 'Admonishments' text is a debate about how to interpret the omen of the solar eclipse and what is a proper response to it. This is not unusual, since omen interpretations and cosmo-political theories are important elements of ancient Chinese thought, appearing in many forms in many texts.

The history of their development is rather complex, and it is especially hard for us to determine how widely a certain cosmo-political concept or a divinatory practice was accepted at a given time ${ }^{64}$ and how these various concepts and practices influenced each other. Because of these difficulties, every piece of information is helpful, so it is worth examining the 'Admonishments' text from this point of view.

From the time of our earliest sources to the late western Han 漢 - when the Confucian state ideology solidified -, we can find many different theories and practices about omen interpretation. But for a top-level categorisation we can discern two basic strategies, two divergent approaches.

${ }^{63}$ Whether this is because this text drew upon historical sources that more correctly portray the influence of persons in the second half of Qi Huan Gong's reign, or because it was fabricated to be so (perhaps using the Zuozhuan as a framework), we cannot tell. If one wants to speculate about the historicity of these events, there are a few interesting dates to note. As mentioned above, Shu Diao led the armies of Qi in 658 B.C.E., while Xi Peng led the army and managed foreign policy in 650 B.C.E. So if there is any historicity of the power struggle described in this text, it must have happened between those two dates.

Using the NASA Solar Eclipse Database I found two relevant eclipses: on 19th of August, 655 B.C.E. a total eclipse was visible in eastern Shandong and north-eastern Yan. On the 2nd of February 653 B.C.E. an annular eclipse happened, its totality was visible in the Central Plains and southern Shandong. Take note that NASA dates assume that year 1 C.E. was preceded by year 0 B.C.E., while historians use 1 B.C.E. Therefore all B.C.E dates from the NASA database have to be shifted by one year.

We do not know about any invasions by Jin, not even abortive ones, but we do know that Jin went through a lot of internal troubles in this decade - the Li Ji Unrest (Li Ji zhi luan 騼姬之 亂). We also know about rising tensions between Jin and Qi. In the autumn of 655 B.C.E., the royal envoy of the king encouraged the Count of Zheng 鄭 to ally with Chu and Jin against Qi. Next year there was internal strife in Jin: Yi Wu 夷吾, a son of the Duke Xian of Jin 晉獻公, had to flee. In 651 B.C.E. the same royal envoy urged the Duke Xian of Jin not to attend the conference of Duke Huan, instead prepare to pacify an upcoming disorder in Qi. But Duke Xian of Jin died later that year and it was his state that fell into disorder.

${ }^{64}$ It is even harder to identify regional differences or differences between different strata of society or between occupations. 
One approach focused on omens that were rare, irregular phenomena, and considered them to be warnings indicating that there are problems with the government. This strategy was ethically motivated (to avoid problems of government), focused on irregularities and usually saw omens in a negative light. ${ }^{65}$

The other approach interpreted omens through correlations with various states (or regions), signals of good or bad fortune for this or that state. This strategy was usually ethically indifferent, it used both predictable (that is cyclical) and irregular phenomena as omens. Omens were seen as indicators of opportunities and of proper timing (when is a good time to attack that state, when to avoid battles, when the harvest will be good, etc.). ${ }^{66}$

According to the available sources, the former strategy, the one interpreting omens as warnings, was popular during the Western Zhou. The 'Day of Supplementary Sacrifice to Gaozong', quoted earlier in this paper, interprets the omen of the crowing pheasant as a warning to correct an error. It is also likely that astrological omens played an important role in the Zhou conquest of the Shang and their Mandate of Heaven (Tianming 天命) theory. ${ }^{67}$

The belief that violating ritual and thus ethical correctness will lead to fateful tragedy is strongly present in the Zuozhuan (Lewis 1999, pp. 134-135), but we can also find some interesting debates which show us that this was a time of changing and clashing beliefs concerning omens. For example, in the 16th year of Duke Xi we find the belief that the phenomena of the sky is caused by yin 陰 and yang 陽, but these are not caused by men nor do they produce good or bad fortune for men (Zuozhuan, Xi 16; Legge 1872, p. 171). ${ }^{68}$

The first mention of field allocation astrology is also in the Zuozhuan. In field allocation astrology, certain sections of the sky are correlated with certain states of China: omens that happen in that section of the sky are interpreted as relating to that particular state. This is a typical case of the second type of omen interpretation strategy.

But in the Zuozhuan this was also received sceptically. In the 17th year of Duke Zhao 昭 a comet was interpreted by field allocation as foretelling fires in four capital cities, including Zheng 鄭. While Bi Zao 裨灶, a diviner, proposed to make a preventive ritual (at the expense of the treasury), but Zi Chan 子產 dissuaded the court saying that 'Heaven is far away'. 69

The belief that unethical actions of men can bring down calamities from Heaven is also present in the Mengzi. ${ }^{70}$ However, the other strategy of omen interpretation became very popular during the Warring States era. We know that there was

${ }^{65}$ A good overview if this approach is covered in Sivin (1969, pp. 5-7).

${ }^{66}$ Kalinowski (1986) offers a good overview of this approach.

${ }^{67}$ See Pankenier (1995 and 1998) on this topic.

${ }^{68}$ For a discussion of this, see Wang (2000, p. 176).

${ }^{69}$ The fire took place in the end, but what matters is that a sceptic opinion was put forward and accepted (Zuozhuan, Zhao 17; Legge 1872, p. 668); for a discussion of this incident, see Wang (2000, p. 83).

\footnotetext{
${ }^{70}$ See for example Mengzi, Gongsun Chou I,4; Legge (1875, pp. 170-171).
} 
plenty of literature on military divination, we can find such passages in early imperial encyclopaedic works like the Huainanzi 淮南子 or the astrological chapter of the Shiji. Almanacs, monthly ordinances, divination by cosmograph (which represented the movement of the counter-Jupiter) and various methods of determining auspicious and inauspicious times for various activities were also very popular. ${ }^{71}$

It might be worth noting that these two strategies do not necessarily contradict each other at the theoretical level, but they do conflict at the level of divinatory practice. For example, the contradiction between the cyclic movement of Jupiter causing good and bad fortune, and virtue and vice causing good and bad fortune can be bridged by saying that virtue means aligning one with these cyclic patterns. Also one can construct causal chains linking ethical or unethical behaviour with metaphysical elements like yin and yang or the wuxing (五行, Five Phases or Five Elements) and prosperity or calamities. Merging these theories together was the accomplishment of Dong Zhongshu 董仲舒 (179-104 B.C.E.). But on a practical level the two approaches diverged: the warning of Heaven interpretation cannot work with cyclic phenomena, while these provided the best omens to determine good and bad timing of various activities.

As the united empire solidified and the central government took control of the vassal kingdoms (by the time of Han Wudi 漢武帝, r. 141-87 B.C.E.), field allocation astrology lost its practical application. As the Confucian state ideology started to coalesce during the 1 st century B.C.E., the Mandate of Heaven theory rose to prominence once more, with its focus on irregular phenomena being interpreted as warnings sent by Heaven in response to governmental mistakes. Regular, cyclic phenomena lost status as omens, but great emphasis was put on precisely predicting them, otherwise they would become omens as deviations from regularity.

With these considerations in mind, let us turn our attention back to the 'Admonishments' text.

First, we should take note what notions are not apparent in the text. There is no mention of field allocation astrology or any other correlative system. Although there are unidentifiable graphs at the beginning of JJNZ \#5 just before they confirm that the omen means calamities for Qi, so we cannot be entirely sure.

Questions of proper timing are also rather marginal. The advices and reforms touch upon the problem of proper timing of corvée labour, but the text does this without giving any metaphysical importance to timing. It appears in the context of tax reductions and other burdens upon the population - as a social problem. Timing is not mentioned regarding ritual or any other activities.

What does appear in the text is the notion that omens are warnings to the ruler to rectify his ways, and harm can be averted with good conduct. Therefore, the omen interpretation in the 'Admonishments' is in line with the Mandate of Heaven theory, the generic attitude of the Zuozhuan or the theories of Mencius 孟子.

${ }^{71}$ The Huainanzi is a good source for many of these beliefs. Although it was written in the early imperial era (presented to the emperor in 139 B.C.E.), it draws upon Warring State sources, often quoting them verbatim. See Major (1993, pp. 5-8). 
Duke Huan's first response to the omen of calamity is to perform a ritual to avert the disaster. This is rejected in the text as ineffectual, since only correcting the mistakes of government can avert the disaster. These debates are similar to the ones in the Zuozhuan. Take note that yin and yang, five phases or field allocation do not even appear as something to be refuted here. This is most likely because the text intentionally focuses upon classical $\mathrm{Ru}$ topics, avoiding speculative metaphysics. ${ }^{72}$

This commitment to the idea that omens are warnings sent by Heaven to help the ruler correct governmental mistakes makes the 'Admonishments' text rather important to the history of omenology. It is one of those missing links between the Mandate of Heaven theory of the Western Zhou and the rediscovered Mandate of Heaven theory of the Han. It is another example that shows that no matter how popular correlative systems were during the Warring States era, they did not completely supersede the 'omens are warnings about governmental mistakes' interpretation.

It is also another example how these conflicting systems lived side by side in different niches of intellectual life. The 'Admonishments' is a text about political ethics (just like most of Mencius). Political thinkers could use one system of omen interpretation in their arguments even though another was used in actual practice by contemporary diviners.

The 'Admonishments' text also mentions an interesting idea: that lack of omens is even worse than omens that are warnings. This is a very convenient argument in the text, because it is a good parallel with Duke Huan who was isolated from critical voices. There is a similar idea in the writings of Dong Zhongshu:

[...] it appeared to me that the interaction between Heaven and man is most awesome! When a country is about to decline due to losing the Way, then Heaven first sends out calamity to reprimand them. Not recognising [the need for] self-inspection, [Heaven] sends further strange phenomena to warn and frighten them. Still not understanding [the need for] change, only then will the fall arrive. ${ }^{73}$

Both the 'Admonishments' and Dong Zhongshu claim that omens are helpful and should be welcomed. The 'Admonishments' parallels this with critical voices: these are helpful and should be welcomed. If the ruler does not hear any criticism, then he should not be content; on the contrary, he should be rather worried, because it means that his connection with the people is severed. The 'Admonishments' draws this conclusion from the parallel with omenology on the JJNZ \#7 slip: lack of omens could mean that the connection between the ruler and Heaven and Earth is severed. Needless to say, a practicing diviner never encounters such a situation, so this theory is only useful for philosophers and politicians.

\footnotetext{
${ }^{72}$ Another explanation may be that the text was written before these theories became very prominent, or the text draws upon early sources.

${ }^{73}$ Hanshu 56.2496-97: 以觀天人相與之際, 甚可畏也。國家將有失道之敗, 而天乃先 出災害以譴告之, 不知自省, 又出怪異以警懼之, 尚不知變, 而傷敗乃至。(The translation is mine - A. M. Sz.) 


\section{Conclusions}

The 'Admonishments' text tells us how Bao Shuya and Xi Peng convinced Duke Huan of Qi to carry out reforms of the government that would strengthen his rule and divert calamities. The duke witnessed an ominous solar eclipse. At first he wanted to exorcise the calamity by prayer, but Bao Shuya and Xi Peng cited the famous parable of Gaozong, where the Shang king witnessed an omen during sacrifice and reformed his government. They argued that omens are warnings that should be welcomed and could be turned into auspiciousness if the ruler is willing to reform his government. They compared omens to criticisms and suggested that the lack of criticism or omens was not a good sign. A ruler who is not criticised should not be sure of his good government; on the contrary, he should start worrying.

Duke Huan realised how bad his situation was, and the two continued to admonish him. They touched upon the problem of ignoring the training of the army, but their chief problem was the influence of sycophants at the court. They complained about Shu Diao and Yi Ya, who were of low status, but gained a lot of power, formed a cabal, indulged the duke and blocked anyone who tried to bring the problems of the government to the duke's attention. And there were problems, the people were overburdened by taxes, untimely corvée labour, and too severe punishments.

The duke then announced a long list of reforms, starting with ritual purity and sincerity during sacrifices, then introduced social and administrative reforms to ease the tax burden and build a better tax base for the country, timed the yearly repairs of roads and bridges (i.e. corvée labour) in a way that they do not conflict with the agricultural activities of the people. Finally, he explained that the good government of the Zhou was based on the principle of selecting officials by merit. The Xia and the Shang dynasties were ruined by the lack of this principle and so did the Zhou decline when they ignored this, but now, he would build his government upon this principle.

The text concludes by reporting the success of these reforms: the invading armies of Jin turned back due to upheavals at home, while the natural calamities and omens turned out to be harmless.

I have shown that we have every reason to consider this text as a Ru one. It focused on ritual correctness followed by the selection of worthy officials. The choice to make Bao Shuya and Xi Peng the protagonists instead of Guan Zhong - whom Confucius criticised for ritual incorrectness and who was later considered to be a proto-Legalist - was most likely also motivated by this type of affiliation of the text.

The omenological interpretation of the text is also interesting. The text does not even mention correlative cosmologies, field allocation astrology or anything similar, despite the popularity of these during the Warring States era. Instead, it considers omens as warnings sent by Heaven in order to urge the ruler to correct governmental mistakes.

Duke Huan was the first of the five great hegemons, and his most important reform was the appointment of officials instead of hereditary offices. In this text this reform is shown as a response to an omen. It illustrates that omens should not be 
treated as disasters, but as helpful warnings. If the ruler heeds criticism, his government will benefit from them.

This feature makes the present text one of the missing links. The 'Admonishments' shows us that this governmental-warning approach to omenology - which was dominant during the Western Zhou and later became state ideology with the Confucian synthesis of the Han - was not abandoned during the time in between. Mencius is another example of this approach to omenology, which again shows the $\mathrm{Ru}$ affiliations of the 'Admonishments' text.

\section{References}

Bagley, R. (1999): Shang Archaeology. In: Loewe, M. - Shaughnessy, E. L. (eds): The Cambridge History of Ancient China. New York, Cambridge University Press, pp. 124-291.

Chen Jian 陈剑 (2006): Tantan "Shangbo (5)" de zhujian fenpian, pinhe yu bianlian wenti 谈谈 《上博(五)》的竹简分篇、拼合与编联问题 [Discussion of the problems of separating, joining and organising bamboo slips from "Shanghai Museum Vol. 5"]. Online publication at http://www.bsm.org.cn/show_article.php?id=204, accessed on Feb. 10, 2015.

Chen Wei 陈伟 (2006): “Jing jian nei zhi”" “Bao Shuya yu Xi Peng zhi jian” lingshi 《競建内之》 《鲍叔牙与隰朋之谏》零识 [Small notes to “Jing jian nei zhi” and “The admonishments of Bao Shuya and Xi Peng"]. Online publication at http://www.bsm.org.cn/show_article. php? id=218, accessed on Feb. 10, 2015.

Chen Xuanwei 陳炫瑋 (2005): Shangbo Chu jianshu “Bao Shuya yu Xi Peng zhi Jien" shiliao niandai wenti 上博楚竹書《鮑叔牙與隰朋之諫》史料年代問題 [The question of the date of historical events in the "Admonishments of Bao Shuya and Xi Peng" from the Shanghai Museum Chu bamboo slips]. Online publication at http://www.bsm.org.cn/show_article. php?id=516, accessed on Feb. 10, 2015.

Dong Shan 董珊 (2007): “Bao Shuya” pian de "kaozhi” yu qi lishi wenxian beijing 《鮑叔牙》 篇的“考治”與其歷史文獻背景 [The “考治” in the “Bao Shuya” bamboo and its historical background]. Online publication at http://www.bsm.org.cn/show_article.php?id=628, accessed on Feb. 10, 2015.

Fan Changxi 范常喜 (2006): “Shangbo wu: Jing jian nei zhi” jian 2 'y' zi shishuo 《上博五競建 內之》简2“彝”字试说 [Preliminary note on the “彝” character on the 2nd slip of the "Shanghai Museum Vol. 5: Jing jian nei zhi"]. Online publication at http://www.bsm.org.cn/show_ article.php?id=206, accessed on Feb. 10, 2015.

Fang Yong 方勇 (2006): Shi shangbo jian "Bao Shuya yu Xi Peng zhi jien" zhongde “yiyuan" yici 釋上博簡《鮑叔牙與隰朋之諫》中的“悒悁”一詞 [The “悒悁” word in the “Admonishments of Bao Shuya and Xi Peng" from Shanghai Museum bamboo slips]. Online publication at http://www.bsm.org.cn/show_article.php?id=490, accessed on Feb. 10, 2015.

Fang Yong 方勇-Hou Na 侯娜 (2008): Chu zhujian zhiji erze 楚竹简札记二则 [Two reading notes on bamboo slips of Chu State]. Changchun shifan xueyuan xuebao (Renwen shihuikexue ban) 长春师范学院学报(人文社会科学版) [Journal of Changchun Normal University (Humanities and Social Sciences)] Vol. 27, No. 1, pp. 52-53.

Gao Youren 高佑仁 (2008): Shi “Jing jian nei zhi” pian 7 de “ze zhi zhu gui shen yue: tian di ming qi wo yi” 釋《競建內之》簡 7 的“則質諸鬼神曰：“天地明棄我矣？”” [Explanation of the “則質諸鬼神曰：“天地明棄我矣 ?"” on the 7th slip of the "Jing jian nei zhi”]. Online publication at http://www.bsm.org.cn/show_article.php?id=834, accessed on Feb. 10, 2015. 
Graham, A. C. (1989): Disputers of the Tao. Chicago-La Salle, Illinois, Open Court Publishing Company.

Guo Yongbing 郭永秉 (2006): Guanyu “Jing jian” yu “Bao Shuya” de ziti wenti 矢于《競建》和 《鲍叔牙》的字体问题 [Regarding the problem of calligraphy of the "Jing jian" and “Bao Shuya"]. Online publication at http://www.bsm.org.cn/show_article.php?id=262, accessed on Feb. 10, 2015.

Hanshu (1962). Beijing, Zhonghua Shuju.

He Youzu 何有祖 (2006): Shangbo wu Chu jianshu “Jing jian nei zhi” zhajian wuze 上博五楚竹 书《競建内之》札记五则 [Five notes on the “Jing jian nei zhi” from Shanghai Museum's Chu bamboo manuscripts Vol. 5]. Online publication at http://www.bsm.org.cn/show_ article.php?id=198, accessed on Feb. 10, 2015.

Henry, E. (1987): The Motif of Recognition in Early China. Harvard Journal of Asiatic Studies Vol. 47, No. 1, pp. 5-30.

Hou Naifeng 侯乃峰 (2008): “Bao Shuya yu Xi Peng zhi Jian” “ren zhi xing san” bu shuo. 《鮑叔 牙與隰朋之諫》“人之性三”補說 [The composition of “人之性三” in the “Admonishments of Bao Shuya and Xi Peng"]. Online publication at http://www.bsm.org.cn/show_article. php?id=818, accessed on Feb. 10, 2015.

Hsu, Cho-yun (1999): The Spring and Autumn Period. In: Loewe, M.-Shaughnessy, E. L. (eds): The Cambridge History of Ancient China. New York, Cambridge University Press, pp. 545587.

Hu Qiong 胡琼 (2007): Shangbo jian “Bao Shuya yu Xi Peng zhi jian” shidu erze 上博簡《鮑叔牙 與隰朋之諫》釋讀二則 [Two philological notes on the "Admonishments of Bao Shuya and Xi Peng” Shanghai Museum bamboo slip]. Online publication at http://www.bsm.org.cn/ show article.php?id=563, accessed on Feb. 10, 2015.

Kalinowski, M. (1986): Les traités de Shuihudi et l'hémérologie chinoise a la fin des RoyaumesCombatants. T'oung Pao Vol. 72, pp. 175-228.

Legge, J. (1861): The Chinese Classics: Vol. I: Confucian Analects, the Great Learning, and the Doctrine of the Mean. Hong Kong.

Legge, J. (1865): The Chinese Classics, Vol. III: The Shoo King or the Book of Historical Documents. Hong Kong.

Legge, J. (1872): The Chinese Classics, Vol. V: The Ch'un Ts'ew with the Tso Chuen. Hong Kong.

Legge, J. (1875): The Chinese Classics: Vol. II: The Life and Work of Mencius. London.

Lewis, M. E. (1999): Writing and Authority in Early China. Albany, NY, SUNY Press.

Li Rui 李锐 (2007): Shangbo (wu) zhaji erze 上博 (五) 札记二则 [Two pieces of reading notes on the Chu bamboo slips in Shanghai Museum Vol. 5]. Guji Zhengli Yanjiuxue Kan 古籍整理 研究学刊 [Journal of ancient book collation and studies] No. 5, pp. 71-72.

Li Xueqin 李学勤 (2006): Shi shi chujian “Bao Shuya yu Xi Peng zhi jian” 试释楚简《鲍叔牙与 隰朋之谏》 [A trial explanation on the bamboo slips of Chu, the Admonitions of Bao Shuya and Xi Peng]. Wenwu No. 9, pp. 90-96.

Lin Zhipeng 林志鵬 (2007a): Chu jianshu “Bao Shuya yu Xi Peng zhi jian” kaoshi sanze 楚竹書 《鮑叔牙與隰朋之諫》考釋三則 [Three philological notes on the “Admonishments of Bao Shuya and Xi Peng" Chu bamboo manuscript]. Online publication at http://www.bsm.org. cn/show_article.php?id=545, accessed on Feb. 10, 2015.

Lin Zhipeng 林志鵬 (2007b): Chu jianshu “Bao Shuya yu Xi Peng zhi jian bushi”楚竹書《鮑叔 牙與隰朋之諫》補釋 [Explanation of the "Admonishments of Bao Shuya and Xi Peng" Chu bamboo manuscript]. Online publication at http://www.bsm.org.cn/show_article.php? id $=618$, accessed on Feb. 10, 2015. 
Liu Lexuan 刘乐贤 (2006): Du Shangbo wu “Jing jian nei zhi” zhaji 读上博五《競建内之》札记 [Notes to reading the "Jing jian nei zhi" from the Shanghai Museum Vol. 5]. Online publication at http://www.bsm.org.cn/show_article.php?id=208, accessed on Feb. 10, 2015.

Ma Chengyuan 馬承原 (ed.-in-chief) (2005): Shanghai bowuguan cang Zhanguo Chu zhu shu 上海 博物館藏戰國楚竹書 (Chu bamboo slips collection of the Shanghai Museum). Volume 5. Shanghai, Shanghai Guji Chubanshe.

Major, J. S. (1993): Heaven and Earth in Early Han Thought - Chapters Three, Four and Five of the Huainanzi. Albany, NY, SUNY Press.

Pankenier, D. (1995): The Cosmo-Political Background of Heaven's Mandate. Early China Vol. 20, pp. $121-176$.

Pankenier, D. (1998): The Mandate of Heaven. Archaeology Vol. 51, No. 2, pp. $26-34$.

Shiji (1959). Beijing, Zhonghua Shuju.

Sivin, N. (1969): Cosmos and Computation in Early Chinese Mathematical Astronomy. In: Science in Ancient China. Researches and Reflections. Burlington, Ashgate. Reprint in 1995, pp. $1-73$.

Wang, Aihe (2000): Cosmology and Political Culture in Early China. Cambridge, Cambridge University Press.

Xuan Jiancong 禤健聪 (2006): Shangbo Chu Jian (wu) lingzha (yi) 上博楚简(五)零札(一) [Part 1 of small notes on the Shanghai Museum Chu bamboo slips Vol. 5]. Online publication at http://www.bsm.org.cn/show_article.php?id=226, accessed on Feb. 10, 2015.

Yang Zesheng 杨泽生 (2006): Du Shangbo jian “Jing jian nei zhi” duan zha liangze 读上博简《競 建内之》短札两则 [Two short notes on the reading of “Jing jian nei zhi” from the Shanghai Museum bamboo slips]. Online publication at http://www.bsm.org.cn/show_article.php? id=225, accessed on Feb. 10, 2015.

Yuan Ying 袁甞 (2014): Shi Shangbojian 'Bao Xuya yu Xi Peng zhi Jian’ zhong de diming 'Fan' 释上博简《鲍叔牙与隰朋之谏》中的地名“范” [The place name “Fan” in the Shanghai Museum bamboo slips]. Zhongguo Guojia Bowuguan Guankan 中国国家博物馆馆刊 [Journal of National Museum of Chinese History] No. 9. pp. 57-61. 